\title{
Efektifitas Peraturan Daerah Kota Padang Nomor 21 Tahun 2012 Tentang Pengelolaan Sampah Di Kelurahan Gurun Laweh Nan XX Kecamatan Lubuk Bagaluang
}

\author{
${ }^{1}$ Laila Afni Rambe, ${ }^{2}$ Muhammad Alwi Dalimunthe \\ ${ }^{1}$ Jurusan Ilmu Syariah, Fakultas Syariah dan Hukum, Universitas Islam Negeri \\ Sunan Kalijaga Yogyakarta \\ 2 Jurusan Hukum Ekonomi Syariah, Fakultas Syariah dan Hukum, Universitas \\ Islam Negeri Imam Bonjol Padang \\ lailaafnirambe20@gmail.com
}

\begin{abstract}
Abstraksi.
Faktor yang melatarbelakangi penulis dalam membahas masalah ini adalah efektifitas Perda Kota Padang Nomor 21 Tahun 2012 tentang Pengelolaan Sampah. Dengan memperhatikan pola sikap dan perilaku masyarakat pasca berlakunya peraturan tersebut. Pertanyaan dalam penelitian ini adalah bagaimana efektifitas Perda Kota Padang Nomor 21 Tahun 2012 di Kecamatan Geh Laweh Nan XX Kabupaten Lubuk Bagaluang. Untuk menjawab pertanyaan tersebut penulis melakukan jenis penelitian lapangan dengan menggunakan teknik wawancara yaitu melakukan wawancara dengan pihak terkait seperti: Kepala Desa, Kepala Desa dan tokoh masyarakat di Desa Geh Laweh. Kemudian penulis menganalisis datanya dengan menggunakan metode analisis deskriptif kualitatif. Dari hasil analisis yang penulis lakukan terhadap data tersebut dapat disimpulkan bahwa berdasarkan penelitian yang telah dilakukan di Kelurahan Laweh Nan XX Kecamatan Lubuk Bagalung Peraturan Daerah Kota Padang Nomor 21 Tahun 2012 tentang Pengelolaan Sampah belum efektif hal tersebut. didasarkan pada tidak adanya kepastian hukum tentang sanksi dan kurangnya kesadaran hukum masyarakat.
\end{abstract}

Kata Kunci : Efektivitas Hukum; Masyarakat; Peraturan Daerah Kota Padang Nomor 21 Tahun 2012 Tentang Pengelolaan Sampah

\begin{abstract}
The background factor of the writer in discussing this problem is the effectiveness of Padang City Regulation Number 21 of 2012 concerning waste management. By paying attention to the patterns of attitudes and behavior of the people after the promulgation of these regulations. The question in this study is how the effectiveness of the Padang City Regulation Number 21 of 2012 in the Geh Laweh Nan XX District of Lubuk Bagaluang District. To answer this question the author conducted a type of field research using interview techniques, namely conducting interviews with related parties such as: chief of the village, village chief and community leaders in the Geh Laweh Village. Then the authors analyze the data using qualitative descriptive analysis methods. From the results of the analysis conducted by the author on these data it can be concluded that based on research that has been conducted in the Laweh Nan XX Subdistrict Lubuk Bagalung District, Padang City Regulation Number 21 of 2012 regarding waste management has not been effective this is based on the absence of legal certainty regarding sanctions and lack of legal awareness of the community.
\end{abstract}


Keywords: Legal Effectiveness; Public, Peraturan Daerah Kota Padang Nomor 21 Tahun 2012 Tentang Pengelolaan Sampah.

\section{Pendahuluan}

Di dalam kehidupan bermasyarakat segala bentuk prilaku masyarakat diatur oleh pemerintah daerah agar tujuan dari bernegara dapat tercapai. Aturan tersebut tentunya bervariasi ada mengenai keagamaan, kehidupan bermasyarakat, pergaulan remaja dan termasuk juga didalamnya mengenai lingkungan. Aturan mengenai lingkungan ini sangat penting mengingat bahwasanya daerah kota Padang selain daerah destinasi wisata yang paling besar, kota Padang juga dapat dikatakan daerah yang rawan bencana alam. Sehingga dengan keadaan seperti itu seluruh masyarakat dituntut untuk selalu menjaga kebersihan lingkungannya baik itu dengan melakukan pengawasan terhadap sungai-sungai yang ada disekitar pemukiman masyarakat atau dengan melakukan penghijauan. Dengan banyaknya jumlah penduduk, aktivitas serta kebutuhan masyarakat juga semakin meningkat baik itu kebutuhan primer, sekunder serta tersier. Hal ini menyebabkan juga produk-produk kemasan yang menjadi sampah setelah digunakan masyarakat semakin melimpah.

Terkait tentang lingkungan, pemerintah daerah kota Padang memiliki banyak peraturan salah satu diantaranya yaitu peraturan daerah kota Padang Nomor 21 Tahun 2012 tentang pengelolaan sampah. Jika diperhatikan dalam konsideran PERDA tersebut terlihat jelas bahwa tujuan dari pembentukan PERDA ini adalah untuk mewujudkan lingkungan yang sehat dan bersih dari sampah sehingga perlu dilakukan pengelolaan sampah secara komprehensif dan terpadu dari hulu ke hilir.

Pengelolaan sampah adalah kegiatan yang sistematis, menyeluruh, dan berkesinambungan yang meliputi pengumpulan, pengangkutan, prosesan, daur ulang atau pembuangan dari material sampah. Sampah tersebut berasal dari sisa kegiatan sehari-hari manusia dan atau proses alam yang berbentuk padat. Sebagaimana tujuan yang diamanatkan dalam PERDA Nomor 21 Tahun 2012 tersebut tentu untuk mencapainya diperlukan juga peran aktif dari masyarakat sehingga tujuan dari PERDA dapat tercapai semaksimal mungkin.

Dengan diundangkannya PERDA Nomor 21 Tahun 2012 pada tanggal 14 desember 2012 menandakan bahwa PERDA ini berlaku secara menyeluruh serta mengikat untuk semua kelurahan yang berada di kota Padang, termasuklah salah satu diantaranya yaitu kelurahan Gurun Laweh. Di kelurahan Gurun Laweh volume sampah setiap tahunnya semakin meningkat. Hal ini disebabkan oleh pertumbuhan jumlah penduduk yang terus mengalami peningkatan sehingga volume sampah sangat mempengaruhi TPA (tempat pembuangan akhir).

Hal di atas mendorong penulis untuk melakukan penelitian lebih jauh dengan judul "Efektivitas Peraturan Daerah Kota Padang Nomor 21 Tahun 2012 Tentang Pengelolaan Sampah di Kelurahan Gurun Laweh Nan XX Kecamatan Lubuk Bagaluang. 


\section{Metode.}

Jenis penelitian yang penulis lakukan dalam pembahasan permasalahan ini ialah Penelitian lapangan (field reseach) yaitu suatu penelitian yang dilakukan dengan mengamati secara langsung, untuk memahami fenomena tentang apa yang dialami oleh subjek penelitian dengan cara deskriptif dalam bentuk kata-kata dan bahasa pada suatu konteks khusus yang alamiah dan dengan memanfaatkan berbagai metode ilmiah.

Instrumen penelitian merupakan alat bantu yang dipilih dan digunakan oleh peneliti dalam mengumpulkan data agar kegiatan tersebut menjadi sistematis dan terstruktur yang bertujuan untuk mempermudah peneliti. Karena jenis penelitian ini adalah penelitian lapangan yang tidak terlepas dari wawancara dan observasi maka yang menjadi instrumen penelitiannya yaitu panduan wawancara, alat rekam, buku catatan dan lain sebagainya (Sugiyono, 2015, p. 222).

Setelah penulis melakukan penelitian ke lapangan, penulis mengindentifikasi masalah yang penulis temukan di lapangan yang terkait dengan permasalahan dalam penelitian ini yaitu efektivitas peraturan daerah kota Padang Nomor 21 Tahun 2012 tentang pengelolaan sampah. Kemudian penulis rumuskan sesuai dengan rumusan masalah dalam penelitian.

Dari seluruh data yang diperoleh di lapangan kemudian di klasifikasikan data yang relevan dengan penelitian. Adapun Tehnik yang digunakan untuk menganalisa data tersebut dalam penelitian ini yaitu metode analisis deskriptif kualitatif, yang dilakukan dengan metode analisis deskriptif yaitu menggambarkan kejadian yang terjadi di lapangan atau menafsirkan data yang berkenaan dengan fakta dan fenomena yang terjadi saat penelitian berlangsung.

Pengelolaan data dilakukan dalam beberapa tahapan. Tahap pertama pengelolaan data dimulai dari penelitian pendahuluan hingga tersusunnya usulan penelitian. Tahap kedua, pengelolaan data yang lebih mendalam dilakukan dengan cara mengolah hasil kegiatan wawancara dan pengumpulan berbagai informasi lapangan. Tahap ketiga, setelah itu dilakukan pemeriksaan keabsahan data hasil wawancara dengan sejumlah narasumber yang dijadikan informan penelitian serta membandingkan data tersebut dengan berbagai informasi terkait. Pada tahap ini, pengolahan data dianggap optimal apabila data yang diperoleh sudah layak dianggap lengkap dan dapat merepresentasikan masalah yang dijadikan objek penelitian. Tahap akhir adalah analisis data dalam rangka menjawab pertanyaanpertanyaan penelitian yang dilakukan dengan pendekatan analisis deskriptif (Adi, 2004, p. 128).

Wawancara adalah salah satu metode pengumpulan data dengan jalan komunikasi yakni melalui kontak atau hubungan pribadi antara pengumpul data dengan responden (Adi 2004, p. 72), dimana arah pembicaraan mengacu kepada tujuan yang telah ditetapkan yaitu mengenai masalah penelitian dalam hal ini memberikan informasi terkait hal itu (Herdiansyah, 2013, pp. 29-30).

Berkaitan dengan judul riset ini, wawancara dilakukan dengan kepala lurah, beberapa staff pegawai kelurahan serta dengan masyarakat kelurahan Gurun Laweh. Peneliti akan mengajukan pertanyaan yang sama kepada semua responden 
guna mendapatkan data informasi yang berkaitan dengan permasalahan yang dibahas dan memudahkan peneliti dalam melakukan pengelolaan data.

Observasi yaitu mengamati gejala yang diteliti, dalam hal ini panca indera manusiwa diperlukan untuk menangkap gejala yang diamati yang kemudian apa yang ditangkap tersebut dicatat dan selanjutnya dianalisis (Adi 2004, 70). Teknik ini dilakukan dengan cara menganalisis dan mengamati secara sistematik gejalagejala yang diselidiki dengan maksud menafsirkannya, mengungkapkan faktorfaktor penyebabnya dan menemukan kaidah-kaidah yang mengaturnya (Emzir, 2012, p. 38).

Berdasarkan riset yang telah dilakukan peneliti mendapat jadwal gotong royong sebagai kebijakan kelurahan dalam upaya mendorong rasa kesadaran masyarakat terhadap kebersihan lingkungan serta sadar akan pentingnya pengelolaan sampah.

Dalam riset ini saya juga melakukan studi kepustakaan dengan cara meneliti dan menelaah karya ilmiah yang sudah pernah ditulis oleh orang lain yang membahas tentang efektivitas Peraturan Daerah Kota Padang Nomor 21 Tahun 2012 Tentang Pengelolaan Sampah, sehingga penulis membedakan permasalahan yang akan penulis buat dengan permasalahan yang sudah ditulis oleh orang lain tersebut.

Irfan Harsya dengan judul penelitian Implementasi Peraturan daerah Nomor 21 Tahun 2012 Tentang Pengelolaan Sampah di Kecamatan Padang Utara Kota Padang. Fokus penelitian yaitu mengenai pengimplementasian PERDA kota Padang dengan hasil bahwa PERDA tersebut belum terimplementasikan dengan maksimal.

Berdasarkan Peraturan Daerah Kota Padang Nomor 9 Tahun 2017 tentang lembaga kemasyarakatan kelurahan mendefinisikan bahwa kelurahan adalah wilayah kerja lurah sebagai perangkat kecamatan dalam wilayah kerja kecamatan dan dipimpin oleh kepala kelurahan.

Adapun kelurahan yang diteliti adalah kelurahan Gurun Laweh Nan XX. kelurahan Gurun Laweh Nan XX adalah salah satu kelurahan di kecamatan Lubuk Begalung, Kota Padang. Kelurahan ini berbatasan dengan kelurahan Parak Laweh dan kelurahan Kampung Durian Padang Timur.

\section{Hasil dan Pembahasan}

\section{Efektivitas Hukum}

Efektivitas itu sendiri adalah keadaan dimana dia (pihak yang berwewenang) diperankan untuk memantau. Pada dasarnya efektivitas merupakan tingkat keberhasilan dalam pencapaian tujuan. Pengukuran tingkat keberhasilan dalam arti tercapainya sasaran atau tujuan yang telah ditentukan sebelumnya. Ketika ingin mengetahui sejauh mana efektivitas dari hukum maka pertamapatama yang harus dapat diukur adalah sejauh mana hukum itu ditaati oleh sebagian besar target yang menjadi sasaran kepatuhannya (Ali, 2009, pp. 22-23). 
Efektifitas hukum dalam tindakan atau realita hukum dapat diketahui apabila seseorang menyatakan bahwa suatu kaidah hukum berhasil atau gagal mencapai tujuannya, maka hal itu biasanya diketahui apakah pengaruhnya berhasil mengatur sikap tindakan atau perilaku tertentu sehingga sesuai dengan tujuannya atau tidak. Salah satu upaya yang biasa dilakukan agar masyarakat mematuhi kaidah hukum adalah dengan mencantumkan sanksi-sanksinya.

Berbicara tentang efektivitas hukum berarti akan membicarakan daya kerja hukum dalam mengatur dan memaksa masyarakat untuk taat serta patuh terhadap hukum itu sendiri. Ada beberapa factor yang terkait yang menentukan efektivitas penegakan hukum (Ni'mah, 2012, p. 60). Oleh karena itu yang menjadi tolak ukur suatu hukum itu dapat dikatakan efektive pelaksanaannya tentunya berdasarkan factor-faktor yang dapat mempengaruhi hukum itu sendiri, yaitu:

a. Kaidah hukum

Factor kaidah hukum itu sendiri adalah masalah yang terjadi atau gangguan terhadap penegakan hukum yang berasal dari hukum/peraturan/undang-undang. Disebabkan karena:

1) Tidak diikutinya asas-asas berlakunya undang-undang;

2) Belum adanya peraturan pelaksana yang sangat dibutuhkan untuk menerapkan undang-undang;

3) Ketidakjelasan arti kata-kata di dalam undang-undang yang mengakibatkan kesimpangsiuran di dalam penafsiran serta penerapannnya (Sibuea, 2016, p. 130).

Dilihat dari segi filosofis bahwa penetapan PERDA tersebut berpayungkan hukum yang lebih tinggi diatasnya yaitu mengingat bahwa pemerintah daerah dilegalkan dalam membuat peraturan berdasarkan pasal 18 ayat 6 Undang-undang dasar republik Indonesia tahun 1945. Hal tersebut bermakna bahwa pemerintah daerah memiliki hak untuk membuat peraturan didaerahnya sendiri dengan tujuan melaksanakan tugas pemerintah.

Sedangkan dari segi yuridis, bahwa PERDA Nomor 5 tahun 1985 tentang kebersihan dalam daerah kotamadya tingkat II Padang tidak sesuai lagi dengan perkembangan keadaan masyarakat sehingga perlu diadakan pembentukan PERDA Nomor 21 tahun 2012 tentang pengelolaan sampah. Selain itu menimbang pelaksanaan ketentuan dari undang-undang Nomor 18 tahun 2008 tentang pengelolaan sampah dan pasal 32 ayat 4 peraturan pemerintah Nomor 81 tahun 2012 tentang pengelolaan sampah rumah tangga sehingga dianggap perlu diatur dengan peraturan daerah.

Dalam sudut pandang sosiologis PERDA kota Padang tentang sampah dibentuk untuk memenuhi kebutuhan masyarakat. Menimbang bahwa dalam rangka pengelolaan sampah secara terpadu perlu dibuat peraturan mengenai pengelolaan sampah agar memberikan manfaat secara ekonomi, sehat bagi masyarakat dan aman bagi lingkungan serta dapat mengubah perilaku masyarakat. Tidak hanya sampai disitu bahwa tujuan dari pembentukan PERDA ini untuk mewujudkan lingkungan yang sehat dan bersih dari sampah. Hal ini sesuai dengan tujuan hukum itu sendiri adalah keadilan, kepastian dan kemanfaatan.

\section{Faktor Penegak Hukum}


Berfungsinya suatu hukum, mentalitas atau kepribadian petugas penegak hukum memainkan peranan penting, kalau peraturan sudah baik tentu didorong oleh penegak hukum yang baik pula (Soekanto, 2007, p. 10). Ruang lingkup dari penegak hukum sangatlah luas sekali. pada tulisan ini yang termasuk kepada penegak hukum akan dibatasi yaitu pada penegak hukum yang secara langsung berkimpung atau berhubungan langsung yang tidak hanya mencakup law enforcement tetapi juga termasuk peace maintenance. Penegak hukum tersebut termasuk dibidang kehakiman, kejaksaan, kepolisian serta pengacara dan permasyarakatan (Sibuea, 2016, p. 131).

Penegak hukum atau orang yang bertugas menerapkan hukum telah melaksanakan tugas dan kewajibannya sebagaimana digariskan oleh hukum yang berlaku. Pemerintah selaku aparatur negara sudah membuat UndangUndang yang berkaitan dengan sampah. Terdapat dalam Undang-Undang Nomor. 18 Tahun 2008 yang mengatur tentang pengolahan dan penanganan sampah. Undang-Undang tersebut menjadi salah satu upaya pemerintah untuk mengatasi sampah yang ada. Hal ini didukung dengan adanya PERDA pada tiap-tiap provinsi.

Sejauh pelaksanaan PERDA tentang sampah mulai diundangkan hingga saat ini pemerintah daerah kota Padang belum maksimal dalam menegakkan hukum. Hal ini dilihat dari tidak ditindak lanjutinya pelanggaran-pelanggaran yang dilakukan oleh masyarakat yang membuang sampah sembarangan. Padahal untuk aturan sanksinya telah dijelaskan dalam pasal 63 yang berbunyi: : setiap orang dengan sengaja membuang sampah tidak pada tempat yang telah ditentukan dan disediakan sebagaimana yang dimaksud dalam pasal 53 huruf d, dipidana dengan pidana kurungan paling lama 3 bulan atau denda paling banyak Rp.5000.000,-.

Kondisi yang dialami masyarakat saat ini dibingungkan dengan dimana sebenarnya letak kepastian hukum mengenai sanksi ini. Tidak diterapkan sanksi tersebut menandakan bahwa pemerintah daerah tidak konsisten dengan aturan atau produk hukum yang mereka produksi. Sanksi tersebut hanya sebatas formalitas semata yang tidak terlihat bentuk pengaplikasiannya.

Namun, terlepas dari pemerintah daerah kota Padang. Sebaliknya bahwa pemerintah kelurahan sudah melaksanakan aturan-aturan yang terdapat dalam PERDA kota Padang tersebut. Adapun upaya yang dilakukan meliputi:

a) Dilibatkankannya masyarakat dalam penanggulangan sampah dengan melakukan pengawasan-pengawasan terhadap sungai-sungai. Sehingga dengan begitu masyarakat berperan aktif dalam penegakan hukum tersebut;

b) Gotong royong dilakukan secara continiue disetiap RW yang berada di kelurahan Gurun Laweh. Kebijakan tersebut dilakukan dua kali dalam sebulan yang dilaksanakan pada minggu kedua disetiap bulannya. Dengan melibatkan seluruh masyarakat serta staf pegawai kelurahan. Aktivitas ini dilakukan dengan pengawasan lansung oleh kepala lurah serta dengan adanya hubungan kerjasama dengan dinas kebersihan.

c) Adanya teguran-teguran kepada masyarakat yang melanggar aturan atau yang tidak mengindahkan program dari pemerintah kelurahan. 
d) Upaya dengan himbauan agar membuat taman-taman disekitaran rumah agar terwujudnya kelurahan yang bersih dan indah.

e) Kedepannya pemerintah kelurahan akan membentuk dan bekerjasama dengan komunitas-komunitas sosial peduli sungai atau peduli lingkungan agar masyarakat tertarik dalam menjaga lingkungan.

\section{Faktor Sarana atau Fasilitas Hukum}

Menurut soerjono Soekanto, sarana dan prasarana yang dalam konteksnya disebut sebagai fasilitas hukum merupakan alat pendukung terwujudnya efektivitas pelaksanaan hukum atau peraturan. Dampak yang ditimbulkan dari fasilitas yang kurang memadai dan representative tersebut akan menjadikan para pihak tidak bisa leluasa untuk menjalankan peraturan (Sofiani, 2010, p. 11).

Sama-sama diketahui bahwa terkait tentang penegakan hukum haruslah disertakan saran atau fasilitas yang menjadi pendukungnya agar penegakan hukum tersebut dapat dilaksanakan dengan semaksimal mungkin. Hal ini tidak juga dapat dipungkiri apabila dihubungankan dengan masalah yang diteliti.

Dalam mendukung pelaksanaan PERDA kota Padang tentang sampah, pemerintah kota Padang telah menyumbang 1 buah gerobak sampah disetiap kelurahannya. Sumbangan itu tentunya saja belum mencukupi kebutuhan gerobak sampah di kelurahan Gurun Laweh mengingat bahwa penduduk kelurahan Gurun Laweh itu mencapai 5000 jiwa. Bahwa peraturan yang telah dibentuk tidak akan dapat berjalan dengan mulus serta sesuai dengan tujuan apabila tidak ada fasilitas dalam pelaksanaannya.

\section{Faktor Kesadaran Masyarakat}

Melihat kesadaran masyarakat, peneliti kembali pada pasal 48 PERDA kota Padang Nomor 21 tahun 2012. Disana dijelaskan bahwa masyarakat berperan aktif dalam pengelolaan sampah dengan: a) menjaga kebersihan lingkungan; b) aktif dalam kegiatan pengurangan, pengumpulan, pemilahan, pengangkutan, dan pengelolaan sampah; c) pemberian usul, pertimbangan dan/ atau saran kepada pemerintah daerah dalam kegiatan pengelolaan sampah; d) pemberian saran dan pendapat dalam perumusan kebijakan dan strategi pengelolaan sampah

Berdasarkan bunyi pasal diatas peneliti memandang apabila peran dari masyarakat sebagaimana yang terdapat dalam pasal 48 PERDA Nomor 21 tahun 2012 terlaksana sesuai dengan harapan, hal itu menandakan dalam diri setiap individu masyarakat terdapat kesadaran hukum. Begitu juga sebaliknya apabila peran masyarakat tersebut tidak dilaksanakan maka dapat disimpulkan bahwa masyarakat Gurun Laweh tidak memiliki kesadaran hukum.

Fakta yang ditemukan peneliti dilapangan dan dikuatkan dengan hasil wawancara bersama Lurah Gurun Laweh bahwa hingga saat ini belum terjalin stimulus respon antara sebahagian besar masyarakat dengan pemerintah kelurahan. Artinya bahwa sebahagian besar masyarakat belum melaksanakan perannya dalam pengelolaan sampah. Sehingga kebijakan apapun dari kelurahan jika tidak didorong dan didukung oleh masyarakat setempat sama dengan sia-sia. Segala upaya telah dilakukan oleh pemerintah kelurahan baik itu sosialisasi pengelolaan sampah, himbauan jangan membuang sampah 
sembarangan namun respon dari masyarakat belum menandakan adanya itikad baik dari masyarakat agar saling mendukung.

Pada saat observasi di lapangan peneliti mengamati seluruh sudut kelurahan, daerah tempat tinggal masyarakat. Berdasarkan observasi tersebut dan dikaitkan dengan Peraturan Daerah tentang Sampah di kelurahan Gurun Laweh Nan XX pada hari selasa tanggal 09 Januari 2019 pada jam 14.00 WIB. Selanjutnya, pengamatan kelompok terhadap tempat sampah yang berserakan atau titik sampah di kelurahan Gurun Laweh Nan XX, banyak sampah disana yang dikumpulkan petugas kebersihan yang selanjutnya untuk dipindahkan. Tempat sampah tersebut memang kotor dan menimbulkan bau yang menyengat, sehingga banyak juga masyarakat yang tinggal didekat tempat sampah tersebut merasa keberatan dan merasa bau akan sampah.

Apalagi tempat tersebut berada dipinggir jalan, sehingga banyak juga masyarakat yang merasa bau sampah pada saat melewati daerah tersebut. Sehingga harus adanya upaya pemerintah kota Padang untuk menegaskan atau menghimbau masyarakatnya agar tidak membuang sampah sembarangan, dan tidak banyak melakukan pembuangan sampah yang nantinya menambah kerusakan lingkungan dan udara sehat (Mariani, 2019).

Kurangnya kesadaran masyarakat disebabkan dari kurangnya kesadaran masyarakat di kelurahan Gurun Laweh karena faktor pendidikan. Hal ini bermakna bahwa banyak dari masyarakat yang berpendidikan rendah sehingga kesadaran dan pemahaman akan hukum juga dapat dikatakan minim. Selanjutnya karena faktor keagamaan yaitu masih banyak masyarakat yang tidak memperdulikan anjuran dalam agama islam agara menjaga kebersihan. Terakhir karena faktor ekonomi, hal ini dijelaskan oleh ibu lurah bahwa masyarakat pelanggar aturan itu dominan masyarakat yang memiliki perekonomian menengah ke bawah. Apatisnya sikap masyarakat yang menganggap bahwa penegakan hukum itu hanya ada pada pejabat menjadikan sulitnya untuk merealisasikan suatu peraturan, alhasil hukum itu tidak diterapkan (Citraningrum, 2013, p. 23).

\section{Faktor Kebudayaan}

Perlu ada syarat yang tersirat yaitu pandangan Ruth benedict tentang adanya budaya malu (shame culture), dan budaya rasa bersalah bila seseorang melakukan pelanggaran terhadap hukum-hukum yang berlaku (guilty feeling).

Berdasarkan keterangan dari sebahagian masyarakat kelurahan Gurun Laweh bahwa masyarakat tidak lagi malu membuang sampah sembarangan. Hal ini terlihat dari telah dilakukannya teguran-teguran terhadap masyarakat yang membuang sampah secara sembarangan namun hingga hari ini mereka tetap masih banyak yang melakukan hal tersebut. Bahkan mereka tidak merasa bersalah apabila ditegur malah mereka saling menyalahkan sesama masyarakat.

Membuang sampah sembarangan, tidak taat pada aturan serta tidak hadir dalam kegiatan sosial lingkungan telah menjadi budaya yang masyarakat anggap menjadi hal yang biasa. Asumsi mereka bahwa tugas mengenai kebersihan itu adalah tugas dari pemerintah. Pelanggaran yang dilakukan secara terus menerus dianggap sebagai suatu hal yang lumrah dan tidak perlu dibesar-besarkan bagi masyarakat. Kondisi masyarakat kelurahan Gurun 
Laweh menunjukkan bahwa telah tertanam dan mendarah dagingnya sifat-sifat pembangkangan dalam diri masyarakat itu sendiri.

\section{Kesimpulan}

Penulis melihat ada dua sisi di dalam memandang Peraturan Daerah Kota Padang tersebut apakah efektif atau tidak. Paraturan Daerah Kota Padang dikatakan efektif apabila masyarakat menyadari akan kebersihan dan mematuhi peraturan tersebut, sehingga dengan menyadari akan kebersihan dan mematuhi peraturan mengenai sampah tersebut, maka dapat dipastikan kelurahan atau lingkungan masyarakat akan bersih dari sampah-sampah. Sebaliknya, apabila masyarakat tidak menyadari akan kebersihan dan mematuhi peraturan, dengan kata lain masyarakat tidak peduli terhadap kebersihan lingkungan, maka dapat dipastikan lingkungan masyarakat akan dipenuhi oleh sampah-sampah yang berserakan. Jadi kesadaran dan kepedulian masyarakat di Gurun Laweh Nan XX sangat penting dalam melihat apakah peraturan tersebut efektif atau tidak.

Penegakan atau pembuatan peraturan bertujuan untuk mencapai kedamaian dalam masyarakat. Masyarakat mempunyai pendapat-pendapat tertentu mengenai hukum. Artinya, efektivitas hukum juga bergantung pada kemampuan dan kesadaran hukum masyarakat. Dengan demikian berdasarkan penelitian yang telah dilakukan dikelurahan Gurun Laweh Nan XX Kecamatan Lubuk Bagalung, Peraturan Daerah Kota Padang Nomor 21 Tahun 2012 tentang pengelolaan sampah belum efektive hal ini berdasarkan tidak adanya kepastian hukum mengenai sanksi serta kurangnya kesadaran hukum masyarakat.

Kesadaran yang rendah dari masyarakat akan mempersulit penegakan hukum, adapun langkah-langkah yang bisa dilakukan dalam meningkatkan kesadaran hukum masyarakat adalah sosialisasi dengan melibatkan lapisan-lapisan sosial, pemegang kekuasaan dan penegak hukum itu sendiri. Kemudian kepada pemerintah daerah kota Padang perlu di tegakkan kembali kepastian hukum terkait dengan sanksi yang seharusnya menjadi efek jera bagi pelanggar aturan.

\section{Daftar Pustaka}

\section{Jurnal:}

Citraningrum F, "Efektivitas Hukum Pengenaan Bea Perolehan Hak Atas Milik Jual Beli Tanah dan Bangunan". Jurnal Hukum Universitas Brawijaya , Volume 1, Nomor 2, 2013, 23.

Ni'mah Z, "Efektvitas Penegakan Hukum penghapusan Kekerasan Dalam Rumah Tangga”. Mimbar Hukum, Volume 24, Nomor 1, 2012.

Sibuea H, "Penegakan Hukum Pengaturan Beralkohol" Jakarta: Pusat Penelitian Badan Keahlian DPR RI, 2016.

Sofiani, T, "Efektivitas Mediasi Perkara Perceraian Pasca PERMA Nomor 1

Tahun 2008 di Pengadilan Agama, Jurnal Penelitian, Volume 7, Nomor $2,2010$.

\section{Buku:}

Adi, R. 2004. Metodologi Penelitian Sosial dan Hukum. Jakarta: Granit. Ali, A. 2009. Menguak Teori Hukum dan Teori peradilan Termasuk Interpretasi Undang-Undang. Jakarta: Kencana. 
Emzir. 2012. Metodelogi Penelitian Kualitatif Analisis Data. Jakarta: Rajawali Pers.

Herdiansyah, H. 2013. Wawancara, Observasi, dan Focus Groups. Jakarta: PT Raja Grafindo Persada.

Sugiyono. 2015. Metode Penelitian Kuantitatif, Kualitatif dan RD. bandung: Alfabeta.

Soekanto, S. 2007. Faktor-Faktor yang Mempengaruhi Penegakan Hukum . Jakarta: PT Raja Grafindo Persada.

Peraturan Daerah Kota Padang Nomor 21 Tahun 2012 tentang Pengelolaan Sampah.

Wawancara:

Yulizar, Lurah Gurun Laweh Nan XX, Wawancara dilakukan pada 07 Januari 2019.

Mariani, Masyarakat, Wawancara dilakukan pada 08 Januari 2019. 